\title{
Attitudes of Presidents and Provosts on the University Library ${ }^{1}$
}

\section{Beverly P. Lynch, Catherine Murray-Rust, Susan E. Parker, Deborah Turner, Diane Parr Walker, Frances C. Wilkinson, and Julia Zimmerman}

This study replicates an investigation conducted by Deborah Grimes in 1992-1993 and published in her 1998 book, Academic Library Centrality. This paper reports the results of interviews conducted in 2004 with the presidents and provosts of six universities and compares them with Grimes' findings. The analysis shows that major changes have occurred in the attitudes of university leaders toward their libraries during the last decade. These new findings provide direction for library leaders as they seek out new models of library service and reshape old models to fit the current environment of American higher education. The findings also point to the emergence of new competencies, skills, and knowledge as essential components of the job of the library director. The results of this study call into question the applicability of the centrality concept to libraries in universities and indicate the need for research that offers a relevant model for use in those settings.

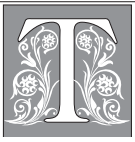

he metaphor of the library as "the heart of the university" gained currency in the late 19 th century. This concept of the library's central importance may have helped the library sustain financial support over the years. But, given the stark fiscal realities of universities in the 21st century, the authors set out to investigate whether this idea of centrality is still powerful enough to secure funding for the library.
This report describes research completed in 2004 that replicates Deborah Grimes' 1992-1993 investigation into the centrality of the university library. ${ }^{2}$ Using Grimes' same research questions, plus an additional question about technology, the authors interviewed several university presidents and provosts. The authors found that, although leaders recognize the symbolic value of the university library, it is the functional role of the library in service to the university's

Beverly P. Lynch is a Professor of Information Studies at the UCLA Graduate School of Education E Information Studies, University of California, Los Angeles; e-mail: bplynch@ucla.edu. Catherine Murray-Rust is Dean of Libraries at Colorado State University; e-mail: Catherine.Murray-Rust@ColoState.edu. Susan E. Parker is Deputy University Librarian and CFO at UCLA Library, University of California, Los Angeles; e-mail: sparker@library.ucla.edu. Deborah Turner is a doctoral student in the Information School at the University of Washington; e-mail: turned@u.washington.edu. Diane Parr Walker is Deputy University Librarian at the University of Virginia; e-mail: dpw@virginia.edu. Frances C. Wilkinson is Interim Dean of University Libraries at the University of New Mexico; e-mail: fwilkins@unm.edu. Julia Zimmerman is Dean of the University Libraries at Ohio University; e-mail: Zimmerj1@ohio.edu. 
mission that ultimately garners budgetary support.

In this article, the concept of the centrality of the university library is explored, especially with reference to the work of Grimes and Judith Dozier Hackman. ${ }^{3}$ Methodologies for the Grimes study and the 2004 replication study are provided, along with a comparison of their findings. Implications for university libraries and librarians are discussed, as are recommendations for acting strategically in today's fiscal environment.

Ultimately, these findings are a reality check for university librarians, confirming that the days of automatic library support are over. Indeed, university administrators expect their library directors to actively compete for funding with deans and others who sit on the provost's council.

\section{The University Library and the Concept of Centrality}

At some point between 1876 and 1920, the phrase "the heart of the university" came to define the role of the library in the academy. In addition to its sentimental connotations, this metaphor was also a useful shorthand during budget talks between library directors and campus administrators. When the 20th-century American university embraced the goals of teaching and scholarship, unquestioned fiscal support appeared to be assured for the research library, which was regarded as essential to attaining these goals. In his landmark study of the quality of graduate education, Allan Cartter wrote, "The library is the heart of the university; no other single nonhuman factor is as closely related to the quality of graduate education," establishing a powerful mid-20th-century link between the library and graduate faculty. ${ }^{4}$

These goals have not changed in the 21st century, nor has scholarly demand for access to depth and breadth in research and teaching materials. However, the means of access and types of materials are in a continuous state of transformation, and libraries are under tremendous pressure to keep up with new technology even while maintaining many of their old ways of operating. Although preeminent research collections remain in print form, collections of digital materials are growing rapidly. These new formats require technological means to gain access and the negotiation and maintenance of elaborate agreements with publishers to purchase. Even as digital purchases expand, the library is expected to maintain its print materials, often when electronic duplicates are available.

While technology can reduce materials to a fraction of their original size, it has yet to decrease demands for physical space in libraries. Large buildings are still necessary to house print collections as well as to provide work and study environments and serve as gateways to virtual resources. A new generation of scholars and students is demanding a new kind of workspace and employing new methods of seeking and finding information. To meet these challenges, the library is replacing study carrels with new, convertible learning spaces. It is also purchasing the software and hardware that students and other researchers need to create knowledge both alone and interactively. The library's instructional mission is even more critical now because students, who readily turn to electronic resources, often are unable to differentiate quality materials from other kinds.

Various forms of scholarly communication used by today's faculty and researchers are also evolving rapidly. Technology is fueling new kinds of publications and forcing scholars who work in traditional modes of publishing to respond to new information and research that can now be transmitted electronically in a matter of minutes. The library is now confronted with defining what role it has to play in this new publishing frontier and determining how to permanently archive materials that are increasingly ephemeral in nature. It remains to be seen how the library will fulfill its traditional obligation to ensure the survival, preservation, and use of the global historical record in all 
formats, and whether the terms of this obligation will change.

The changing demands of disciplines and technology are creating extraordinary demands on university budgets at a time when political and financial support for higher education is declining. Monetary constraints are also felt within the library itself, and directors are often caught between economic forces over which they have little or no control. Frequently, librarians find themselves competing with other campus organizations for money as well as space.

University budgets generally have remained static in the last 20 years while spending demands have skyrocketed. Maintaining and improving budget levels is increasingly dependent on fundraising efforts. The allocation of resources within the university is an extraordinarily difficult balancing act, with resources being shifted in times of retrenchment. Librarians who saw their purchasing power erode in the 1980s and 1990s are finding that the library as "the heart of the university" argument has lost much of its power in budget talks, and other arguments and strategies are now required.

\section{Hackman's Centrality Continuum}

Most university budgetary decision-making is political and can be correlated to a department's institutional power. In the 1980s, many universities tried to rationalize difficult budget decisions by making allocations based on the extent to which departmental activities contributed to their central missions. Several investigations were conducted at this time to develop a theory to guide these allocation decisions. In her research, Hackman concluded that departments most central to the university mission lost fewer resources or gained resources while units least central to the mission lost resources. ${ }^{6}$

Although Hackman's centrality construct was a continuum, she found it more useful to characterize departments as "core" or "peripheral." More specifically, she identified departments as "core gain- ers" or "core losers" and "peripheral gainers" or "peripheral losers." In her study, academic departments and schools were core units, while most administrative and support units were peripheral units, with libraries falling into the latter category. Among Hackman's core gainers were computer science, business, and engineering, while core losers were teacher education, fine arts, and languages. Peripheral gainers were development, admissions, and administrative computing. Peripheral losers were student affairs, counseling, and physical plant.

Hackman acknowledged that her designations would likely be controversial and concluded that future investigations should focus on refining categories. "The importance of centrality in understanding how organizations allocate resources is the most distinctive finding of the present study. Differences between core and peripheral units are the cornerstone of the proposed theory. Any future research should clarify the concept of centrality and refine the understanding of how to measure what is core and what is peripheral."

\section{Grimes' Work on Academic Library Centrality}

Deborah Grimes took Hackman's concept in another direction in her study on the centrality of the academic library. Grimes sought to identify indicators of academic library centrality by interviewing 14 chief executive officers (CEOs) and chief academic officers (CAOs) at seven universities in the United States. Although she was aware of the work of Hackman, she did not try to locate the place of the library on a centrality continuum or in one of Hackman's broad categories. Instead, she focused on the metaphor "the library as the heart of the university." Based on her interviews with chief executives, she concluded that the metaphor should be abandoned. Instead, she proposed a new metaphor: "the academic library as a crossroads community."

After asking her respondents what the phrase "the library is the heart of the uni- 
versity" meant to them, Grimes concluded that the library's practical roles were more important to leaders than its symbolic role. For example, administrators observed that the key mission of the library was to build collections and to provide centrally located facilities where students could study. Despite this, the physical library as a place fostering intellectual growth remained a potent symbol. One respondent observed that faculty and students championed the library principally because of this powerful symbolic role, and therefore the library was less likely than other areas to receive budget cuts. In at least one case, the symbolic significance of rankings by the Association of Research Libraries (ARL) as a "measurable indication" of the quality of the library was cited as extremely important to faculty morale, recruitment, and retention.

However, administrators predicted the library's symbolic role would change and perhaps decline in the future, to be eclipsed by new modes of information organization. Administrators nonetheless assumed libraries would play a significant role in developing technical access to information. More than one administrator suggested that the influence of information and telecommunications technologies would change the symbolic role of the academic library forever, that "the days of great comprehensive libraries are gone," and that "the symbolism of access to data and information will grow." 8

\section{Centrality Project 2004}

In 2004, the authors replicated Grimes' study to identify and understand changes in the notion of centrality that have occurred in the last decade.

\section{The Research Design}

Presidents, chancellors, provosts, or chief academic officers at six universities were interviewed. The research team developed four key questions and several follow-up questions, which investigators asked each administrator. Each interview was about one hour in length. The interview sessions were recorded and later transcribed by individuals who did not participate in the study in any other way. One investigator did the initial thematic coding, which two investigators reviewed. All investigators reviewed transcripts, coding, and analysis.

\section{Research Questions}

Four central issues guided both the 19921993 and 2004 studies. The researchers used the same thematic questions, supplemented by probes or follow-up questions. The 2004 study also included a new question about technology in libraries.

1. Metaphor: What does the phrase "the library is the heart of the university" mean, if anything, to you? Follow-up: Does this phrase equate with the mission of the academic library? Do you think it is an accurate statement on this campus?

2a. Standards and Technology: The Association of College and Research Libraries (ACRL) standards for university libraries state that centrality is an underlying assumption of the university library mission:

The library is of central importance to the attainment of any university's goals. It is an organic combination of people, print and electronic collections, technology, and buildings, whose purpose is to assist users in the process of transforming information into knowledge. Information and knowledge are central to the attainment of any university's goals. The ways in which information is collected, stored, and distributed within the institution will, in large measure, determine the level and success of scholarship and knowledge. ${ }^{9}$

Do you think this is an accurate statement? Follow-up: Do you think it reflects the reality on this campus?

$2 \mathrm{~b}$. What comes to mind when you think about libraries, technology, and library collections? Follow-up: How do you think that libraries should effectively manage their increasing reliance on technology? 
2c. Briefly, how is the university librarian or library director involved in university decision making? Does the library have a symbolic role on campus? Does this symbolic role give it protected status in resource allocation decisions? In what ways does the symbolic value show up?

3a. Mission: If we accept that the mission of the university is teaching, research, and service, is there a difference between the university's mission and its priorities? Follow-up: How does the library contribute to this mission? To priorities? Under what conditions do library matters become a top priority? Under what conditions do they become an emergency? How do you identify an emergency?

$3 b$. At this institution, which is more important-teaching, research, or service? Does the percentage of graduate to undergraduate students affect your view of the library's contribution to the university's mission? Do you have a certain level of comfort or expectation about the library's contribution to the mission? If so, what do you examine to determine if the library is meeting its mission? Does the amount of research conducted by academic units of the university affect your view of the library's contribution to the university's mission? To its priorities?

4. Resource Allocation and Institutional Comparisons: In your resource allocation decisions and retrenchment plan, what criteria do you apply to the library? Would you equate these with centrality? Follow-up: Some research suggests that university administrators view what the faculty and students say about the library as more important than comparisons with other libraries. How do you feel about this observation? Who on campus is most influential in your decisions regarding library allocations? Who outside the library is influential?

5. Indicators of Centrality: Which of the following possible indicators do you believe are relevant to a library's centrality within the university?

- Acquisition of outside funding

- Engagement of librarians in research
- Quality of personnel and quality of collections

- Campus visibility

- Participation in decision making

- Service to other units

- Circulation statistics for digital materials

- Symbolic or practical role

- National prestige/reputation/ARL ranking

- Research or paradigm development

- Innovative applications of technology

- Substitutability

- Use

- Proportion of graduates

- Innovation

- Relationship with other universities

- Geographic uniqueness

- Involvement of library director and librarians

\section{1Wrap-up Questions}

What makes you most proud of the library? Is there anything that makes you least proud? How has the library or library director helped you in your own work recently? Do you have any other comments?

\section{The Institutions}

Six public universities in the United States, founded between 1804 and 1965, are represented in this study. Their student populations range from 15,000 to 28,000 . Five offer bachelor's, master's and doctoral degrees; one awards bachelor's and master's degrees. Library collection sizes range from 1.3 to 5 million volumes. Four of the institutions are ARL members. The library directors at each institution report to the university provost or the equivalent, and all but one director has faculty status. Performance measurement is an important activity in each library, with each engaged in assessment using either LibQUAL+ or locally developed instruments.

\section{Findings}

Metaphor

Many of the 2004 participants seemed to want the statement "the library is the heart of the university" to be true. One responded 
nostalgically with a personal recollection from student days at Cambridge, where "they have a fairly good library.... a place where people seemed to go to congregate because that is where the research collections were." As Grimes found a decade earlier, those for whom the metaphor resonated spoke of both the library's symbolic and physical significance. Respondents described the library as "the big information fount," "the lifeblood," the "symbolic depository of knowledge," or "the psychological center" of the university.

According to administrators, the library's role as a repository of print collections was still important and none seemed to believe information technology would supplant the library, nor would printed sources of information become superfluous any time soon. Even while acknowledging that faculty are more likely to conduct virtual research, leaders still viewed the library's role as a physical repository as an important one. As one CAO stated it, the library remains "the heart of where the 'stuff' is."

This same CAO acknowledged, however, that the role of the library as a physical place at the heart of the university is changing, and that for students, the library is "becoming more of a social center and less of an archival center." Another asserted that library centrality rings true for students because "for undergraduates, it's a center physically," a place where they spend time and get work done. One respondent compared his current institution with his experience at another, where he observed that an underutilized library "became overnight ... a hub of student activity" after the building was renovated and expanded.

For two administrators, the metaphor of the library as the heart of the university was not valid. One president said that the phrase is "a marketing slogan that's meant to convey the centrality of the library to try to make sure it stays uppermost in the minds of the administration." Another observed that the question was timely precisely because the meaning and importance of the library were changing. This president identified competition for institutional dollars and an increasing focus on scientific research as reasons the metaphor no longer works. He reported that deans pressing for funding for the sciences have little interest in the library, "that the library's well-being is not their problem."

This same president also saw evidence that the traditional symbolic significance of the library is losing its global hold. Citing a recent meeting with several heads of German universities, he noted that these leaders have stopped talking about their great libraries as the core of their institutions. Instead, they are focused on the difficulties of competing for research funding. Similarly, he observed that nations such as Australia that are engaged in actively building higher education systems did not have a long tradition of great libraries.

This same CEO was the only respondent to hint at electronic publishing as a potential new role for libraries. He mused that among his colleagues "most of the talk about publishing has to do with how to cut the price of journals" and wondered why "one hears relatively little talk about electronic publishing as a function of the libraries."

Presidents acknowledged the library's powerful symbolism. One leader observed, "Libraries end up representing in part what the whole university is about." Several CEOs pointed out how the library's symbolic role was reflected in its physical placement in the center of campus. One noted that the library "is the largest and perhaps most attractive campus building and a gathering place." Another described the symbolic importance of the library building after the campus recovered from a natural disaster. One CEO observed, "The library is the place where the symbolic and practical depiction is made of what the university does academically."

In addition to a central physical presence, CAOs agreed part of the library's symbolic value stemmed from its historical role of providing resources for research. "For the faculty the library stands for my 
resources that enable my research and to a lesser extent my teaching," said one administrator. Some leaders recognized the library as a power center on campus, with one CAO noting that the chancellor's office was located in the library, and another observing that competition for space in the library building was fierce.

\section{Standards and Information Technology}

Even while they acknowledged the symbolic and physical importance of the library, many respondents said that they felt the centrality of the library was diminished and that technology was the primary reason. They pointed out that there are now many alternative sources of information and people are using them.

When asked for their reactions to the ACRL statement that centrality is the underlying assumption of the library's missions of helping scholars transform information into knowledge and collecting, storing, and distributing information within the university, presidents were either noncommittal or suggested the statement was incomplete. They particularly noted that, for the average faculty member and student, the world is digitized and can be accessed from a computer. Provosts observed, "So few faculty now require their students to use the library, and that tends to argue that it is losing its place as the center or heart of the university." These statements assumed using the library required going to a physical location. CAOs suggested that libraries need to make faculty and students aware that the electronic resources they use are provided and paid for by the library.

CEOs and CAOs understood that their campus libraries provide databases and other electronic information sources, and they seemed to take it as a given that this is a part of the library's role as "a central information source [that] is critical to the university." Only one CEO went further than this, stating that "the library is the heart of the university" means that the library is "a reliable, continued repository of information" [emphasis added]. This individual also spoke of the library's role in certifying the reliability of information. "I add reliable because for students today, perhaps for faculty (but I hope not), but for students certainly, the web provides so much information that we have no capability at least easily to verify what is accurate in that source of information. Whereas, the library at least, I think most of us feel comfortable that if you are storing it or providing us access ... then you are in some way giving us a degree of assurance that this information is valid and reliable information."

Respondents were encouraged to describe what came to mind when they thought about libraries, technology, and library collections. Presidents found that "technology is inextricably linked with library service," observing that the number and roles that the library must play has multiplied. Not only do librarians and staff help people learn how to use the new electronic resources, but the library also offers access for faculty and students wherever they are working. Librarians also are expected to "provide digital access for students and faculty," regardless of the physical location of the repository, and to provide "unpublished or otherwise rare materials."

One president saw a natural cooperation between libraries and information technology units, while another perceived an increasing overlap in "typical" library activities and "typical" information technology activities, predicting that "there will be continual assessment of the[ir] organizational relationship in the next two decades." CAOs identified technology as a driver behind the addition of library services and content, including improved document delivery services, greater access to journals online, and more online collections. One was aware of the existence of widespread consortia that help to deliver electronic content.

Affirming that both physical and virtual collections remain essential, provosts asserted that the case can and should be 
made for libraries to sustain both. Even as they viewed technology as a consolidating force for library services and functions, participants were divided about how they envisioned the library's ability to manage complex digital environments. Many of their comments had to do with how to find the best mixture of staff expertise, service functionality, and collaboration.

\section{Mission}

Presidents and provosts generally agreed that the library contributes fundamentally to the research and teaching missions of their institutions, with research taking priority. One provost observed, "The research component of the libraries is so key now. This really is a vote for the scholarship of universities and research, not so much for the teaching mission. There is no huge misalignment between priorities and the mission. ... tying research to the educational mission makes a lot of sense for universities."

When asked if they equate the library as the heart of the university with the mission of academic libraries, administrators were cautious and nuanced in their replies. One respondent acknowledged that "it's a catchy phrase" but did not feel that it effectively describes the mission of the library. One president described the metaphor as a "marketing slogan." Another said,

I think it did [that is, the phrase was equated with the mission of the academic library] but I am not sure it does any longer. It still works if it is the means to access, but not as a physical space...I think if one accepts the notion that learning really is an active pursuit of meaning and knowledge, then the library is presumably the repository of those resources whether they are virtual resources or physical. So few faculty now require their students to use the library, so that tends to argue that it is losing its place as the center or heart of the university.
Several leaders responded that the mission of the academic library is to provide access to reliable information. To the extent that libraries are evolving to do that, the statement might still equate with the mission of their institutions. But it was apparent to them that a shift has occurred. They all agreed that, to be seen as the heart of the university, today's library must provide access to students and faculty where they are rather than limiting itself to a physical location to which patrons must come to find materials. In the words of one respondent, "being the heart of the university today really means that at a student's desk, in a student's bed if he or she is using a wireless computer, for a faculty member sitting on their back porch, that library should be accessible." No respondents felt that the stereotype of the library as place with "closed stacks and librarians running around shushing people" equated with the mission of the library today.

While Grimes found that provosts and presidents were ambiguous and reluctant to prioritize among research, teaching and service, the authors of the present study found that only presidents were noncommittal in 2004. One remarked, "Who wants to take the gospel apart? You know, it's cheap and it's there-use it." CAOs were more forthcoming in making distinctions. Research university provosts said research was a higher priority, while provosts responsible for primarily undergraduate institutions placed teaching first. Most presidents and provosts agreed that the library contributes to research and teaching, and supports service to a lesser extent. Two provosts specifically mentioned support for the community as a priority, but one president disagreed, stating, "I am not sold on the notion that great university libraries have to provide services as local public libraries."

When asked about the role of the library in university decision making, administrators reported that the library dean or director serves as an equal on the deans' council and reports to the 
provost. Provosts reflected more than presidents on the conscious choice of placing the library in the academic side of the house, with an appropriate central role in decision making. According to one provost, the librarian is at the table "to complement the intellectual work of the schools, [and is] effectively integrated into leadership and decision making" as consultant, adviser, and decision maker. One provost, however, reported that the head of the library "is present at a lot of significant conversations because she is charismatic, visionary, energetic, smart, and engaging. I don't think it is organizationally determined."

Neither presidents nor provosts wanted to say that libraries were protected in resource allocation decisions. Leaders acknowledged that, while libraries require a minimum level of support, library funding requests don't carry the same weight as proposals from other deans unless a clear connection between university enrollment and student learning outcomes is made. During times of retrenchment planning, one president observed that the library is no longer automatically protected. "I can remember 25 years ago or so sitting on a committee that oversaw the library, and having no sense of controversy between the deans and libraries about priorities. That is not the case now. The deans come in and they've got complaints over funding the library all the time. It reflects the division of priorities between funded sciences and in a sense the rest of the university." Another president commented: "In the difficult budget environment we are dealing with now, our highest priority is to preserve faculty positions. The library is critical to academics, so we are going easier on the library than on other administrative units."

Most respondents acknowledged that the digital revolution and the high costs of innovation have made funding libraries a higher priority in the last decade. As one provost summed up, "The library becomes a top priority when either the service falls below the expectations of the customers (students and faculty primarily), when access to information resources is failing to meet expectations, and where the physical infrastructure is such a deterrent for utilization that you have to look at it-and you don't really even want to get to that stage."

Four presidents had mixed feelings about when the library becomes a budgeting priority. "Yes, [the library becomes a priority] in the sense that it will receive minimum funding, but no, in the sense that it does not generate a tremendous constituency that is lobbying hard for resources for the library," said one. Another observed that the library budget and services have been preserved, and that there has never been talk of cutting the acquisitions budget, but that many on campus have no idea that there have been cuts elsewhere in the library. One president revealed, "I have had to go in and provide central discretionary funds because the protective system is not working properly."

While the weight and value of the library's symbolic role continues to be reflected in budget allocations, competing fiscal imperatives such as the acquisition of digital collections and maintenance of print ones may have greater influence on decision makers. The evidence is that the library has successfully made its funding case to the university, given that the library in general has had to cope with smaller funding cuts than other academic units. In being spared major cuts, the underlying expectation was that libraries would develop greater efficiencies and find a balance between growing digital collections while maintaining their print ones. Provosts were especially astute in noting that it is increasingly necessary for library directors and deans to make the case internally to library staff about the new realities of university budgeting decisions and financial support.

Administrators observed that relying on the symbolic role of the library edifice during budget talks is a weak financial strategy. Presidents noted that excellent 
service records and the librarian's participation and visibility in the shared governance process as a member of the faculty had more clout during budget talks. Provosts were even more emphatic about the importance of the library's practical role and participation in campus life. CAOs strongly advocated librarians promoting contributions to the academic environment and student life such as reliable, ubiquitous access to virtual resources, inspirational spaces for study and reflection, and creature comforts like food and coffee.

\section{Resource Allocation and Institutional Comparisons}

When it comes to assessing the library, all respondents said they pay attention to qualitative input such as faculty and student feedback as well as quantitative assessments, particularly comparisons with other libraries. CEOs tended to favor internal feedback over comparative data. "I am more affected by what the students and faculty say," said one, while another observed, "Anecdotal comments are a very important source of information." Still another stated, "You are naturally going to be sensitive to people in your own community who are talking to you about things."

CEOs and CAOs expressed similar concerns about the value of comparative data. Three CEOs stated that they rely on a mix of the two-faculty and student input and comparisons with other libraries. Only one CEO said that comparative data had a strong influence: "In the end, frankly, the external measure of quality is going to have to be what any serious university uses. It is not just a quantitative measure, but a general assessment of quality." Two CEOs expressed serious concerns about what data is being compared: "As long as rankings tell the story of [paper] collections, they are telling absolutely the wrong story. They are irrelevant," and "Benchmarking can be very valuable. What you get concerned about is people who play games and benchmark against the worst case scenarios."
These concerns were echoed by CAOs, most of whom questioned the reliability of library comparisons: "I don't know what it means to say our library is not as good as... [that of] a bigger school," said one. Two others observed, "The comparisons are really financial comparisons," and "The opinion I have had on some of the national ranking systems is that there is a tendency to look at head counts of employees, to look at outmoded indicators. It is time to upgrade the criteria and look at libraries in a different or modern light."

Grimes also found that most CEOs and CAOs agreed that what faculty and students say about the library is more important than comparisons with other libraries. One emphatically stated, "I'm not interested in comparisons," while another said, "Numbers alone do not tell you if a collection is suitable." Regarding comparative data, Grimes found a decade ago that some administrators questioned collection size as a basis for comparison. This concern continues in the current study and appears to be increasing.

In terms of forces outside of the library influencing allocation decisions, CEOs in the present study identified the CAO as the one with the most budgetary clout. Additionally, one CEO noted that "accrediting reports would provide valuable feedback." Another said that input from faculty leaders and "other academic leaders, deans" would also be useful. One CEO stated, "The relationship between the provost and the director of libraries is the first and most important relationship." This relationship may be why most of the CAOs identified the library director as being the most influential factor in library allocations. However, two CAOs indicated that the faculty "are the main drivers."

\section{Indicators of Centrality}

Presidents agreed on three library centrality indicators: the library's ability to acquire outside funding, visibility and leadership on campus, and circulation 
and interlibrary loan statistics. Innovative applications of technology, quality of personnel and collections, and quality of service to other campus units were also important indicators. CAOs identified quality of library personnel and collections, participation of library leadership in high-level university decision-making and service to other units of the institution as their top indicators. Most provosts also agreed that innovative technology applications of technology and library use were important indicators.

In both studies, respondents were asked to decide which of the list of 17 indicators are related to centrality. They could pick as many as they wished. There were two striking differences between the results of the two studies. In 2004, all CEOs agreed that acquisition of outside funding, campus visibility, and statistics for use, circulation, and interlibrary loans were measures of value. Outside funding and visibility were not identified a decade earlier in Grimes' investigation as strong centrality indicators. Several of Grimes' interviewees thought that outside funding was irrelevant for academic libraries because libraries are not research-generating units. It seems most of the respondents in the 2004 survey appeared to interpret the term to stand for the qualities that make a library valuable to the parent institution. The second difference between the two studies pertains to instruction and research collaboration and innovative applications of technology. These centrality indicators were not selected by Grimes' respondents as centrality indicators but strongly advocated by 2004 administrators.

The only centrality indicator that was not chosen in either study was librarian involvement in the faculty senate or its committees. This is not to suggest that such participation is not important for individual librarians or for libraries, but only that presidents and provosts do not view faculty senate service as a measure of library value.

\section{Wrap-up Questions}

In 2004, presidents and provosts did not differ greatly in their responses from their 1990s counterparts, although presidents were more likely to comment on overall excellence and operational efficiency when asked what they were most proud of in terms of their libraries. Provosts emphasized quality of service and innovative programs or services, and they were more aware of positive faculty attitudes toward the library. Most of the presidents and provosts also expressed disappointment in their institutions' inability to support libraries adequately. Five respondents expressed regret over less-than-optimal budgetary support for the library, with two specifying staffing and space needs that had gone unmet. This, too, echoes Grimes' findings, in which many respondents regretted not being able to offer more financial support to the library.

In response to a question about how the library or library director contributes to the administrator's own work, only one 2004 respondent had not used the librarians' expertise or library service in some way. All of the others provided examples-often more than one-in which the library or library director participated proactively in university affairs, helped forward the administration's agenda, or provided important information for governance and planning. Two had received help of a more individual scholarly nature. This is a marked change from Grimes' study, in which only two respondents had called upon the services of their librarians.

\section{Summary of 2004 Results}

Many of the 2004 respondents reported having made significant efforts to make no cuts or minimal ones to their respective library budgets. Administrators frequently followed up this assertion with comments about how libraries contributed to the university mission and how the library measured up in assessment efforts. Most spoke of library support of the university's research and service mission as a criterion 
that is used in determining funding. In describing criteria considered for retrenchment in a way that positions the library amongst the highest campus priorities, one provost commented that "it's the number of sections for students, its library holdings, and it's how are the faculty doing sort of issues. Retaining top faculty ... I mean you look at the fact that some $50 \%$ of all our grants and contracts come from $7 \%$ of our faculty ... I worry about the collections ... because I know what impact that has on the research mission." Another said, "The library is critical to academics, so we are going easier on the library than on other administrative units." Others made similar comments or expressed how challenging it would be to recover from making substantial cuts that hampered library collections. Of the few who reported making similar cuts to the library, many described efforts to "backfill" soon after. Such responses reflect participants' knowledge of how having a quality library collection supports the mission, specifically research, graduate students, and faculty recruitment and retention.

The next most frequent response regarding criteria used for resource allocation decisions and retrenchment planning was assessment. Numerous direct and indirect comments were made about effective measures of both usage and program costs. A few wondered if currently used measures were as relevant and accurate as they could be. One president observed, "You have to identify which capabilities are mission-critical and which are ancillary and you have to go through a process... . One of the management challenges is that we do not have good qualitative or precise qualitative criteria." Another president, who noticed how busy the library was, wondered if the activity was for academic or other purposes such as Web surfing and suggested that "we might have to do additional analysis in order to be sure that the need is as the need appears to be."

Respondents were asked what arguments were most cogent regarding library budgetary allocations. In 2004, adminis- trators indicated that assessment and use were the most influential factors. This is a departure from Grimes' study, which revealed that formal mechanisms - library dean budget recommendations, campus budget processes, and comparison statistics - were most important in influencing resource allocations. One president underscored this new attitude in 2004: "Can you correlate library collections and services to academic achievement and research excellence? If you can show evidence of this relationship, you've got the best possible argument."

Although present findings show that some formal mechanisms are still being used, the 2004 results indicate the attitudes of decision makers have shifted. Library operational costs, usage, and services now are being considered with an eye to measuring effectiveness. This finding may reflect both the current academic culture of assessment, economic challenges, and increases in demands on the library budget.

Furthermore, two unique responses appeared in the data: one president discussed an increasing number of complaints made among senior administrators regarding the central library system as being overfunded. He said complaints could be motivated by observations by deans that departmental libraries better met departmental needs; departments desired a different use of space that had been allocated to a branch library; or a reflection of "the division of priorities between funded sciences and in a sense the rest of the university." Another president described advances in information technology applications in support of library access and use as being a cogent argument for library allocations.

\section{Comparison of 2004 Study Results with Grimes' Results}

Grimes' study found that faculty and student comments about the library were generally most important to administrators. When asked to name individuals or departments whose arguments are "most 
cogent regarding library decisions," most administrators cited formal groups such as library committees, administrative councils, student organizations, faculty senates, and community support groups. Grimes also found that Library deans or directors (CLOs) and other academic deans had influence but they were not highlighted to the degree that they are in the current study. Further, the CEOs interviewed by Grimes did not mention the CAOs as being the most influential in decisions regarding library allocations.

The increasing influence of library deans and directors that is noted in the 2004 study may be due, in part, to their having done a better job of educating administrators about the many issues facing libraries today.

Participants in both Grimes' study and the 2004 study were asked what criteria they used in making resource allocation decisions and retrenchment planning, specifically what criteria was used with regard to library funding. Interview questions to this end were included to provide participants with an opportunity to discuss specific indicators of centrality that they applied to the library.

In Grimes' study, respondents indicated the importance of the physical library space, and there were library building projects underway on several of the campuses. Some noted that the library as a gathering and study place reflects a symbolic campus role. Others noted that the ARL rankings have an impact on the symbolic role of the library in terms of representing library quality. In the 2004 study, there was favorable evidence for a continued belief in the symbolic role of the library. As one provost noted, the library "has sacred status in at least the faculty world, both functionally and also in a certain odd, almost ritual or religious way. There is an almost moral undertone to faculty communications about the library, which is a huge resource as people rethink the role of the library in the future." Grimes' respondents cited the library's symbolic role in resource allocations, when the library was championed by faculty or students' willingness to earmark tuition increases for library improvements. Administrators supported the idea that the library is taken care of during the budget allocation because it has a symbolic role and serves a central function.

Presidents and provosts in 2004 also observed that the library's symbolic role is changing because of advances in information and communication technologies. Some suggested that now it is actually the library's functional role that may give it budget protection. However, one respondent thought that the advance of electronic access to information and publications signaled the end of great comprehensive university libraries. Another agreed with the idea of technology reducing the library to a building and the books it contains. A completely opposing view was that the symbolism of the library will broaden as it changes from the concept of an edifice or warehouse to becoming an encompassing source of information.

Presidents and provosts invoked about half of the centrality indicators from Grimes' original study. Three values emerged that were not on Grimes' list including campus visibility, outside funding, and technological innovation. Even so, university presidents and provosts did not completely embrace the idea of university library centrality. Instead, they proffered that the metaphor must be replaced with a concept that describes the library's measurable value to the institution, such as immediacy and substitutability. Their bottom line was that the library needs to determine what the university values, and how to speak about those things to make clear the contributions of the library toward enhancing or furthering these values.

\section{Summary-Results and Implications}

Respondents in 2004 did not find the mission of the library to be equivalent to the "library as the heart of the university" metaphor. Instead, they asserted that the intellectual and physical aspects of the library reflected its importance to the 
university. For presidents and provosts, the practical role of the library outweighs its symbolic role. Furthermore, the library needs to employ strategies that connect what it does to the values and mission of the university.

The results of this investigation are relevant to the academic library community in several ways. First, the issues discussed with these campus leaders are important to all academic libraries and librarians. The comparison of the 2004 data with Grimes' findings of ten years ago reveals important changes in the thinking of university leaders about the university library and its leadership.

Second, while most CEOs and CAOs understand changes in technology, they still need library directors to educate them about today's university library, what it does and why it is important to continue supporting so-called legacy collections and services as vigorously as electronic ones. University leaders need to understand the dual role of and research needs for libraries as repositories of physical and virtual collections, or funding will likely suffer.

Third, library directors need to understand the different role that is required of them as a team member of the provost's council and to develop new competencies, skills, and knowledge needed to fulfill this role. Directors must also ensure that librarians and staff understand their new responsibilities; create clear lines of authority and responsibility in the library organization; and delegate more authority to associate university librarians.

Fourth, library directors must develop and deploy strategies for promoting how the library contributes to the university mission and the creation of knowledge. This message must be tailored to decision makers who sit on the provost's council as well as to the library's various patrons. If campus leaders value innovation, visibility, and acquisition of outside funding, as indicated in this study, then librarians know what strategic issues to emphasize. Additionally, library staff needs to be edu- cated about the new realities of finance and governance.

Fifth, this study can help academic librarians understand what their efforts at teaching information literacy, aligning librarians' status with that of faculty, and ranking the university librarian with deans have meant. All of these efforts have helped to align the library as closely as possible with the core mission of the university. Libraries have positioned themselves as a critical component of the teaching, research, and service mission of the university and have expended much effort to convince key campus players of this.

\section{Conclusion}

The presidents and provosts participating in this study were well aware of how technology has transformed the way scholars attain access to materials. They acknowledged that the library is an essential tool for researchers and recognized that the library director is working hard to provide this access to scholars and students, regardless of their physical location. As one president observed, "The library does a very good job, but it is under enormous pressure."

In an emblematic sense, academic administrators still view the library as the heart of the university, a symbol of the intellectual purpose of the institution. However, they believe the library's primary mission is providing access to scholarly materials. The library's physical building is important as a gathering and study space for students, and at least some respondents underscore the importance of having attractive and pleasant library facilities that foster student gathering.

To the extent that priorities and values may differ from mission, the days of the library's ability to control what is important are gone. Serving a public good is no longer enough to ensure funding and administrative support. To secure support, the library must now demonstrate how it serves the university mission.

Because presidents and provosts emphasized the importance of the external 
role the library director plays in conveying this message to key audiences, the library director can develop strategies based on this feedback. For example, library directors must delegate more authority and responsibility to their deputies and associate directors. These lines of authority and delegations of responsibility within the library should be clear, visible, and well understood at all library staffing levels. The benefits to the library of the director's fulfillment of external roles and duties should also be well understood within the library.

The library must articulate its strategy based on university needs. The library director should determine what these needs are and how the library can help fulfill them. This study suggests that directors can find fertile approaches by examining university concerns that mirror some of the provosts' and presidents' newly stated indicators of centrality - such as innovation, campus visibility, and acquisition of outside funding - and then linking the library's strategic issues and actions to them. In addition, the director can use administrative relationships at the provost's council to market and communicate this strategy verbally as well as with a written strategic plan aligned with the university's priorities.

The results of this replication study show that major changes have occurred in the attitudes of university leaders toward their libraries during the last decade. These new findings provide direction for library leaders as they seek out new models of library service and reshape old models to fit the current environment of American higher education. These findings also point to the emergence of new competencies, skills, and knowledge as essential components of the job of the library director. The results of this study call into question the applicability of the centrality concept to libraries in universities and indicate the need for research that offers a relevant model for use in those settings.

\section{Notes}

The authors are grateful to Deborah Jeanne Grimes, Shelton State Community College, author of the original study, and to the other 2003 UCLA Senior Fellows who are not listed as authors, including James K. Bracken, The Ohio State University; Virginia Danielson, Harvard University; Amy Dykeman, University of North Carolina at Charlotte; Lisa Janicke Hinchliffe, University of Illinois at Urbana-Champaign; Erica C. Linke, Carnegie-Mellon University; Sara Lowman, Rice University; Don Panzera, Library of Congress; Patricia Promis, University of Arizona; and Sarah Barbara Watstein, UCLA. In addition, thanks also go to Anne Throckmorton, doctoral candidate at the University of Virginia, for her invaluable assistance in shaping the final version of this article.

1. The authors presented an earlier version of this paper and research findings at the 2005 ACRL conference in Minneapolis, Minnesota.

2. Deborah Jean Grimes, "Centrality and the Academic Library" (PhD diss., University of Alabama, 1993).

3. Grimes, "Centrality"; and Judith Dozier Hackman, "Power and Centrality in the Allocation of Resources in Colleges and Universities," Administrative Science Quarterly 30 (1985): 61-77.

4. Allan M. Cartter, An Assessment of Quality in Graduate Education: A Comparative Study of Graduate Departments in 29 Academic Disciplines (Washington, D.C.: American Council on Education, 1966).

5. Aaron B. Wildavsky, Politics of the Budgetary Process, 3rd ed. (Boston: Little Brown, 1979); and Gerald R. Salancik and Jeffrey Pfeffer, "The Bases and Uses of Power in Organizational Decision-Making: The Case of the University," Administrative Science Quarterly 19 (1974): 453-73.

6. Hackman, "Power and Centrality," 61-77.

7. Ibid., 75 .

8. Deborah Jean Grimes, Academic Library Centrality, ACRL Publications in Librarianship 50 (Chicago: Association of College and Research Libraries, 1998).

9. Association of College \& Research Libraries, "Standards for University Libraries: Evaluation of Performance," reprinted from College and Research Libraries News, Sept. 1989: 679-91. 


\section{At the Heart of Today's

(n)
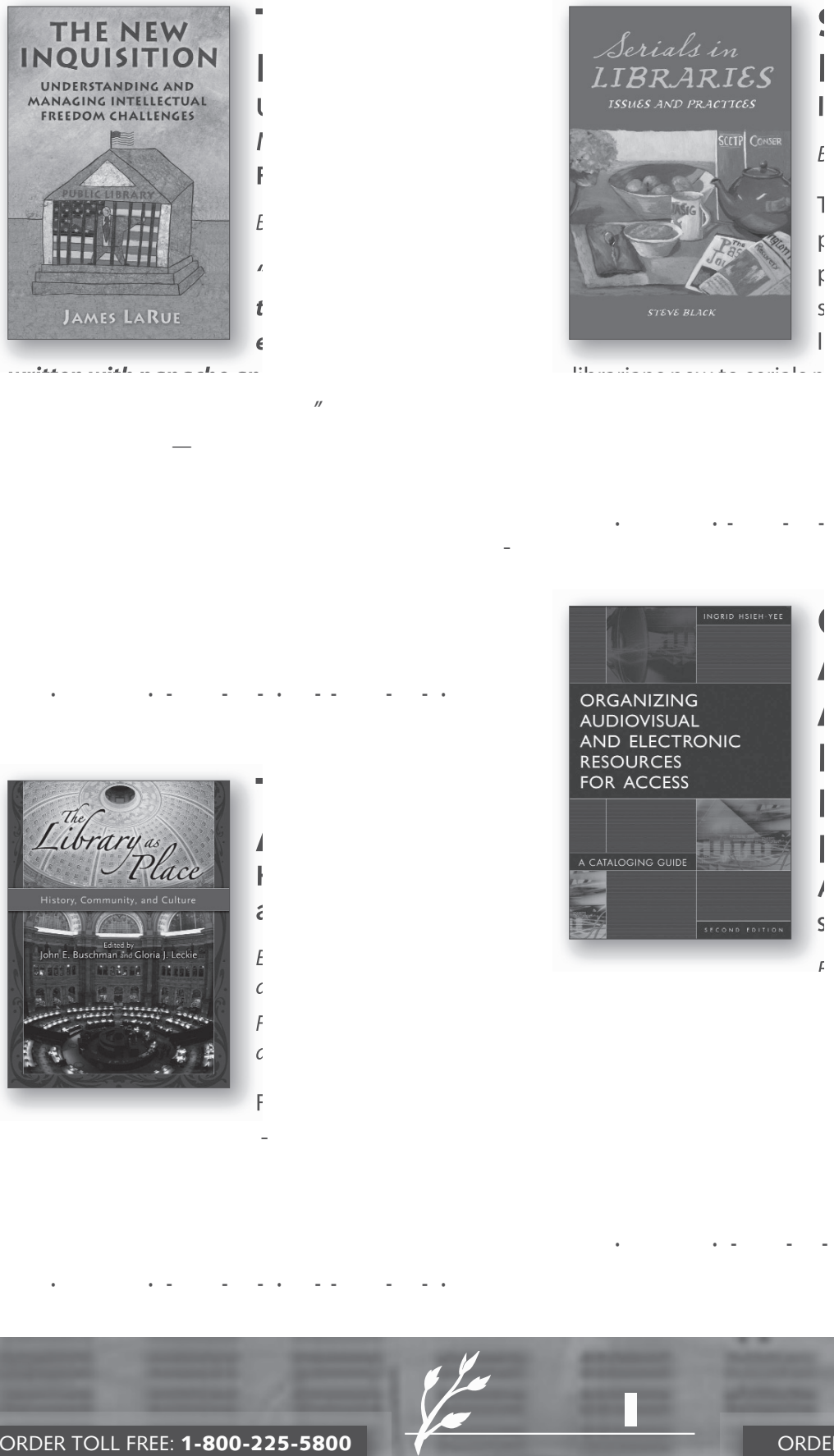